Article

\title{
Influence of Heat Treatment and UV Irradiation on the Wettability of Ti35Nb10Ta Nanotubes
}

\author{
Joan Lario*, Vicent Fombuena, Ángel Vicente and Vicente Amigó \\ Instituto de Tecnología de Materiales, Universitat Politècnica de València, 46022 Valencia, Spain; \\ vifombor@upvnet.upv.es (V.F.); avicente@mcm.upv.es (Á.V.); vamigo@mcm.upv.es (V.A.) \\ * Correspondence: joalafe@posgrado.upv.com; Tel.: +34-696-520-123
}

Received: 18 November 2017; Accepted: 29 December 2017; Published: 7 January 2018

\begin{abstract}
The implant osseointegration rate depends on the surface's topography and chemical composition. There is a growing interest in the anodic oxidation process to obtain an oxide layer with a nanotube morphology on beta titanium alloys. This surface treatment presents large surface area, nanoscale rugosity and electrochemical properties that may increase the biocompatibility and osseointegration rate in titanium implants. In this work, an anodic oxidation process was used to modify the surface on the Ti35Nb10Ta alloy to obtain a titanium nanotubes topography. The work focused on analyzing the influence of some variables (voltage, heat treatment and ultraviolet irradiation) on the wettability performance of a titanium alloy. The morphology of the nanotubes surfaces was studied by Field Emission Scanning Electron Microscopy (FESEM), and surface composition was analyzed by Energy Dispersive Spectroscopy (EDS). The measurement of contact angle for the $\mathrm{TiO}_{2}$ nanotube surfaces was measured by a video contact angle system. The surface with the non photoinduced nanotubes presented the largest contact angles. The post-heat treatment lowered the F/Ti ratio in the nanotubes and decreased the contact angle. Ultraviolet (UV) irradiation of the $\mathrm{TiO}_{2}$ nanotubes decrease the water contact angle.
\end{abstract}

Keywords: beta titanium alloys; $\mathrm{TiO}_{2}$ nanotubes; surface modification; UV irradiation

\section{Introduction}

The main reason for surgical revisions is bone deterioration, and low osseointegration rates that end in implant failure. Improving this rate depends on the material's composition and surface topography [1]. Titanium alloys must display mechanical compatibility with substituted bone, which is achieved through a combination of low a Young's Modulus and high flexural and fatigue strength [2]. Efforts made in the past years have focused on developing $\beta$ titanium alloys with a high content of refractory elements, such as $\mathrm{Nb}, \mathrm{Ta}, \mathrm{Mo}$ or $\mathrm{Zr}$, to improve the bone compatibility and long-term performance of biomedical implants [3]. These new alloys present lower density and Young's Modulus than the stainless steels and $\mathrm{Co}-\mathrm{Cr}$ alloys employed as biomaterials [4]. The elastic modulus of the implant material is decisive to control the load transfer. This phenomenon is related directly to prosthesis loosening. The closer the elastic modulus of the implant material is to bone, the better the load transfer between the implant and bone [5]. Powder metallurgy technology (PM) allows beta titanium alloys to be produced with non-soluble phases, where the microstructure is achieved through solid-state diffusion.

Of the several commercial surface treatments employed to modify the roughness and topography of the titanium implants, sandblasting and acid etching are the most widely used in the industry. The combination of both treatments has been demonstrated to improve osseointegration rates compared with machined implants, or by using just with one of them [6,7]. Titanium and refractory elements, employed as $\beta$-stabilizing elements, can be subject to anodic oxidation and may form 
an oxide layer on their surfaces [8,9]. Nelson et al. showed that the anodized implants present a higher removal torque $(83 \mathrm{~N} \cdot \mathrm{cm})$ than the machined implants $(57 \mathrm{~N} \cdot \mathrm{cm})$, which means greater torque required to remove implants may be interpreted as an increase in the strength of bone integration [10]. The anodic oxidation process in electrolytes with fluorine content attracts researchers' interest because it allows a nanotube morphology on titanium surfaces to be obtained [11,12]. This nanoscale modification has been demonstrated to enhance protein adsorption and cell-implant interaction, and to improve osteoblast proliferation compared with the commercial surface treatments currently employed in implants [11]. Sista et al. (2013) observed that the titanium anodized surfaces presented a high expression of fibronectin and collagen genes compared with polished acid etched surfaces [12]. Both proteins mediate the adhesion of osteoblasts onto the implant surface, and the anodized surface supports greater cell adhesion strength to the underlying surface which improves osseointegration rates.

The factors that influence cell attachment to the surface layers of nanotubes are wettability of a hydrophilic or hydrophobic nature, surface roughness that increases surface energy and chemical composition, and oxide layer properties that enhance the material's corrosion resistance [13]. The biocompatibility of titanium alloys results from a thin titanium oxide layer that is present on the metal surface. This native oxide layer, which is $1-5 \mathrm{~nm}$ thick, lowers metal ion release rates and plays a key role toward osseointegration at the interface between bone and the titanium implant. The corrosion resistance of the surface oxide layer's is influenced by the material's composition and by the parameters employed during the anodization process [14-16]. The nanotube oxide thickness layer increases with anodization time [9]. The nanotube diameter grows by applying an increasing voltage applied during the anodic oxidation process [17].

The objective of the present work is to study the effect of the anodic oxidation process on the wettability, topography and roughness of a Ti35Nb10Ta surface obtained by conventional $\mathrm{P} / \mathrm{M}$ technology.

\section{Materials and Methods}

\subsection{Powder Metallurgy Process}

A beta titanium alloy with nominal composition Ti35Nb10Ta, was prepared by a powder metallurgy process using blending elemental (BE) powder, which was provided by Atlantic Equipment Engineers (AEE, Iselin, NJ, USA): Ti $99.7 \%, \mathrm{Nb} 99.8 \%$ and Ta $<48 \mu \mathrm{m} 99.8 \%$ purity and $1-5 \mu \mathrm{m},<8 \mu \mathrm{m}$ particle size respectively. The Ti35Nb10Ta alloys were pressed at $700 \mathrm{MPa}$. The ternary titanium alloys were heated in a vacuum sintering furnace $\left(<10^{-4} \mathrm{mbars}\right.$, Carbolite Gero GmbH \& Co., Neuhausen, Germany) to $800^{\circ} \mathrm{C}$ at $15^{\circ} \mathrm{C} / \mathrm{min}$, were held at that temperature for $30 \mathrm{~min}$, and were finally heated to $1350{ }^{\circ} \mathrm{C}$ at $10^{\circ} \mathrm{C} / \mathrm{min}$. Finally, they were held for $180 \mathrm{~min}$ and cooled at $10^{\circ} \mathrm{C} / \mathrm{min}$.

\subsection{Surface and Chemical Characterization}

A microstructural analysis was carried out to identify phases, morphology, homogeneity and distribution by optical microscopy under a Nikon (Nikon Inc., Tokyo, Japan) LV100 optical microscope. Metallographic preparation was carried out by acid etching with Kroll solution ( $3 \mathrm{~mL} \mathrm{HF}, 6 \mathrm{~mL} \mathrm{HNO}$, $100 \mathrm{~mL} \mathrm{H}_{2} \mathrm{O}$ ) to reveal Ti35Nb10Ta microstructures.

The effect of the anodic oxidation process on the topography of the Ti35Nb10Ta titanium alloy was qualitatively analyzed by Field Emission Scanning Electron Microscopy (FESEM ULTRA 55, ZEISS, Oberkochen, Germany). The inner diameter, wall-thickness and nanotubes density were determined by the ImageJ image analysis software (Image J 1.50b, National Institutes of Health, Bethesda, MD, USA).

Surface roughness was analyzed by a Confocal Microscopy (FRT CFM, FRT GmbH, Gladbach, Germany). Three measurements were taken for each specimen according to ISO 4287:1997. The 100X NA0.9 objective was employed, with $1 \mathrm{~nm}$ resolution on the " $z$ " axis, and one at $0.4 \mu \mathrm{m}$ on the " $x$ " and " $y$ " axes. The surface analysis area was $134 \mu \mathrm{m} \times 178 \mu \mathrm{m}$. A data analysis and 3D topography were 
performed with FRT Mark III $^{\circledR}$ (FRT GmbH, Gladbach, Germany). The mean roughness $\left(R_{a}\right)$, peak to valley roughness $\left(R_{z}\right)$, quadratic average roughness $\left(R_{q}\right)$ and maximum roughness height $\left(R_{\max }\right)$ were calculated as the typical height parameters. Space descriptive parameters were calculated, including the medium roughness value of the peaks above a profile plane $\left(R_{p k}\right)$, the medium roughness value of the valleys below the profile plane $\left(R_{v k}\right)$, and the biggest difference between the maximum and average surface heights $\left(R_{p}\right)$. This range of parameters was selected in order to include the relevant parameters capable of describing and explaining the surface topography of the studied titanium alloys. The microchemical surface analysis was run with an Energy Dispersive Spectroscopy (EDS, Oxford Instruments, Abingdon, UK).

\subsection{Anodic Oxidation Surface Treatment}

The Ti35Nb10Ta powder metallurgy samples were wet-ground with 220-1500 grit silicon carbide (SiC) paper before starting the anodic oxidation process. The anodizing experiments were performed in the electrolyte composed of $1 \mathrm{M} \mathrm{H}_{3} \mathrm{PO}_{4}$ and $0.8 \mathrm{wt} \%$ of NaF, in a DC Power Supply SM 400-AR-8 (Delta Elektronica, Zierikzee, Netherlands). Anodic oxidation was performed in a two-electrode cell by using the titanium sample as a working electrode (anode) and the $316 \mathrm{~L}$ stainless steel as a counter electrode (cathode), at room temperature, and not under mild stirring conditions. The anode and cathode were maintained in parallel with a separation distance of $20 \mathrm{~mm}$. The anodization voltages employed to grow nanotubes were 15 and $35 \mathrm{~V}$, which were applied for $45 \mathrm{~min}$. After the anodic oxidation process, samples were cleaned in a sodium bicarbonate solution for $30 \mathrm{~min}$ to neutralize the electrolyte. Then samples were immersed in batches with purified water for $20 \mathrm{~min}$ and were dried in a warm air stream. Heat treatment was carried out in a vacuum sintering furnace $\left(<10^{-4}\right.$ mbars $)$ at $320^{\circ} \mathrm{C}$ for $30 \mathrm{~min}$ at the heating rate of $5^{\circ} \mathrm{C} / \mathrm{min}$. After the heat treatment, the samples were cooled in a vacuum to room temperature.

\subsection{Wettability Characterization}

Contact angle measurements were taken by the sessile drop method. The images were captured using a contact angle video based system "Easydrop Standadrd FM140" (KRÜSS GmbH, Hamburg, Germany). The contact angle between the drop and the substrate was analyzed by the "Drop Shape Analysis SW21" commercial software (DSA Version 1.90.0.14, KRÜSS GmbH, Hamburg, Germany).

At least 10 measurements were taken of each sample and the average values were calculated. The maximum error did not exceed $5 \%$. To determine surface energy, four different liquids were used as test liquids: diiodomethane (stabilized, 99\% purity) supplied by Acros Organics (Acros Organics, Geel, Belgium), formamide (reagent grade ACS), and glycerol ( $99 \%$ purity) supplied by Scharlau Chemie S.A. (Scharlab S.L., Barcelona, Spain); and double-distilled water. The contact values of the four used test liquids for the contact angle measurements are observed in Table 1. The surface free energies of the different alloys were calculated by the Owens-Wendt Equation (1), which takes into account the nonpolar and polar contributions to the total surface free energy value. The Owens-Wendt model gives the long-range dispersion $\left(\gamma^{d}\right)$ and the short-range polar $\left(\gamma^{p}\right)$ components of surface free energy, where $\gamma_{s}$ is the surface free energy of the surface (SFE) of the surface and $\gamma_{L}$ the SFE of the liquid.

$$
\gamma_{L}(1+\cos (\theta))=2\left(\left(\gamma_{L}^{d}+\gamma_{S}^{d}\right)\right)^{0.5}+2\left(\left(\gamma_{L}^{p}+\gamma_{S}^{p}\right)\right)^{0.5}
$$

$\theta=$ Calculated contact angle from the shape of the drop.

$\gamma_{L}^{d}=$ Long - range dispersion component of surface energy for liquid.

$\gamma_{S}^{d}=$ Long - range dispersion component of surface energy for surface.

$\gamma_{L}^{p}=$ Short - range dispersion component of surface energy for liquid.

$\gamma_{S}^{p}=$ Short - range dispersion component of surface energy for surface. 
Table 1. Characteristics of the different employed test liquids.

\begin{tabular}{cccc}
\hline Liquid & $\gamma_{L}^{d}\left(\mathrm{~mJ} / \mathrm{m}^{2}\right)$ & $\gamma_{L}^{p}\left(\mathrm{~mJ} / \mathbf{m}^{2}\right)$ & $\gamma_{L}\left(\mathrm{~mJ} / \mathbf{m}^{2}\right)$ \\
\hline Water & 22.0 & 50.2 & 72.2 \\
Glycerol & 34.0 & 30.0 & 64.0 \\
Diiodomethane & 48.5 & 2.3 & 50.8 \\
Formamide & 32.3 & 26.0 & 58.3 \\
\hline
\end{tabular}

\section{Results}

A microstructure is a relevant property that influences the tensile strength, corrosion and fatigue resistance of titanium alloys. Figure 1 presents the tested alloy's microstructures. The microstructure showed a heterogeneous phase composition, which was composed predominantly of a $\beta$ equiaxial grain with a remaining $\alpha+\beta$ phase due to poor diffusion during the sintering process. The $\alpha+\beta$ regions with lower contents of refractory elements presented high chemical heterogeneity. As the studied alloys presented a retained $\beta$ phase of more than $20 \%$, they were classified at room temperature as $\beta$ alloys [18].
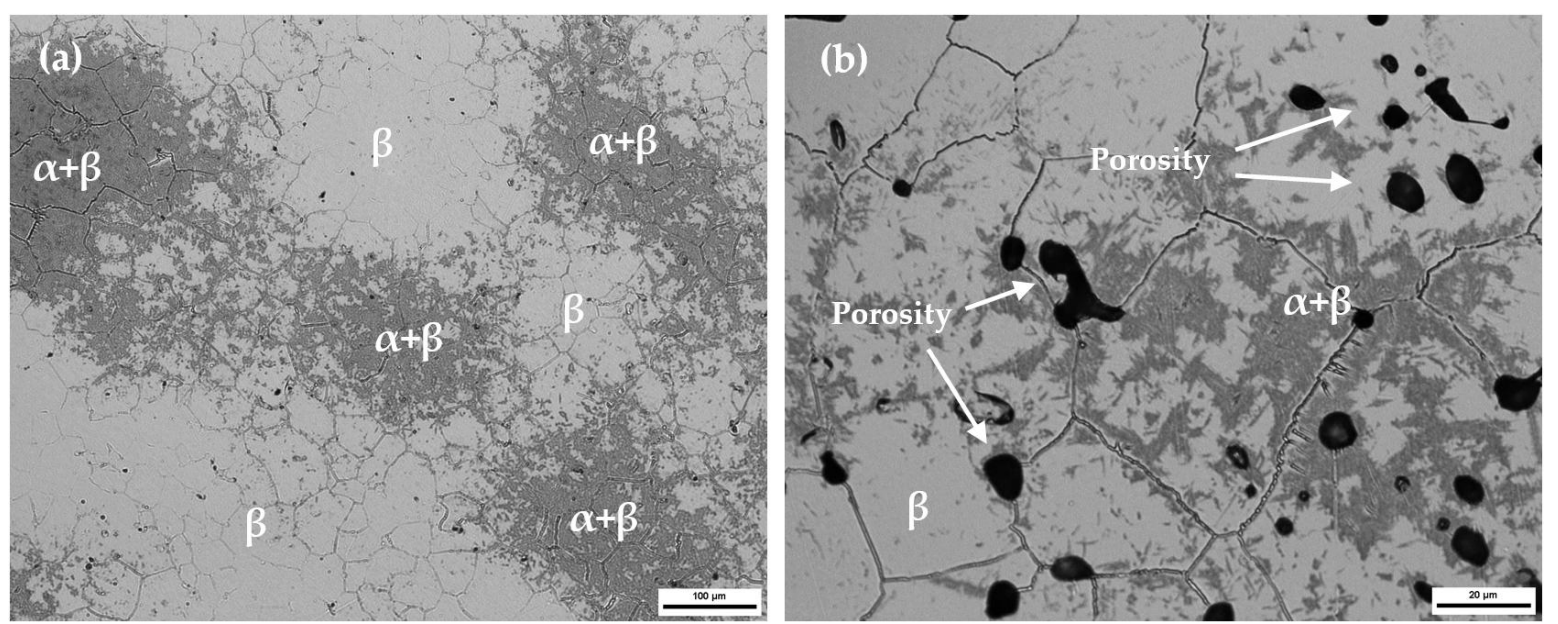

Figure 1. Microstructure of the P/M Ti35Nb10Ta alloy (a) Heterogenous phase composition; (b) $\alpha+$ $\beta$ region.

The mechanical characteristics of the Ti35Nb10Ta alloy have been published in a previous article and are summarized in Table 2 [19]. The P/M Ti6Al4V and Ti CP Grade 2 properties are also reported in this table for comparison purposes. A large amount of $\beta$ stabilizing elements decreases diffusion during sintering. This effect implies lack of diffusion, which results in high residual porosity (Figure 1b) that enhances the stress concentration effect and decreases mechanical properties. A higher content of beta stabilizer elements on the studied titanium alloy, compared with Ti6Al4V and Ti CP, had a significant effect by lowering Young's Modulus. Lower Young's Modulus values could minimize bone atrophy due to the stress shielding effect, which increases the implant durability [2-4].

Table 2. Characterization of the Ti35Nb10Ta alloy.

\begin{tabular}{cccc}
\hline Alloy & UTS $\mathbf{( M P a )}$ & $\boldsymbol{E}(\mathbf{G P a})$ & $\boldsymbol{\rho}_{\boldsymbol{r}} \mathbf{( \% )}$ \\
\hline Ti35Nb10Ta [19] & $827 \pm 29$ & $80 \pm 4$ & $97.4 \pm 0.1$ \\
Ti6Al4V [18] & 960 & 110 & 99 \\
Ti Cp Grade 2 [18] & 414 & 103 & 96 \\
\hline Note: UTS: Ultimate Tensile Strength; $E=$ Young's Modulus; $\rho_{r}=$ Relative density.
\end{tabular}


The FESEM results confirmed the presence of nanotubes on the Ti35Nb10Ta substrates fabricated by the anodic oxidation process (Figure 2). Based on these FESEM images, the inner diameter was estimated. The nanotubes inner diameter increased with the higher voltages employed during anodization process [20]. Nanotubes were uniformly distributed over the entire surface. The nanotubes average diameter was $38 \mathrm{~nm}$ for $15 \mathrm{~V}$ and $55 \mathrm{~nm}$ for $35 \mathrm{~V}$ employed on the anodization process [20].

Chemical composition and topographical features are some of the most relevant surface properties for implants because they influence the osteoblastic response and enhance the osteoconductive process [21,22]. For this reason, the elemental composition of the oxide layer and the surface topography of the anodic oxidized samples were studied. The energy dispersive X-ray analysis results of the studied titanium alloys are summarized in Table 3.

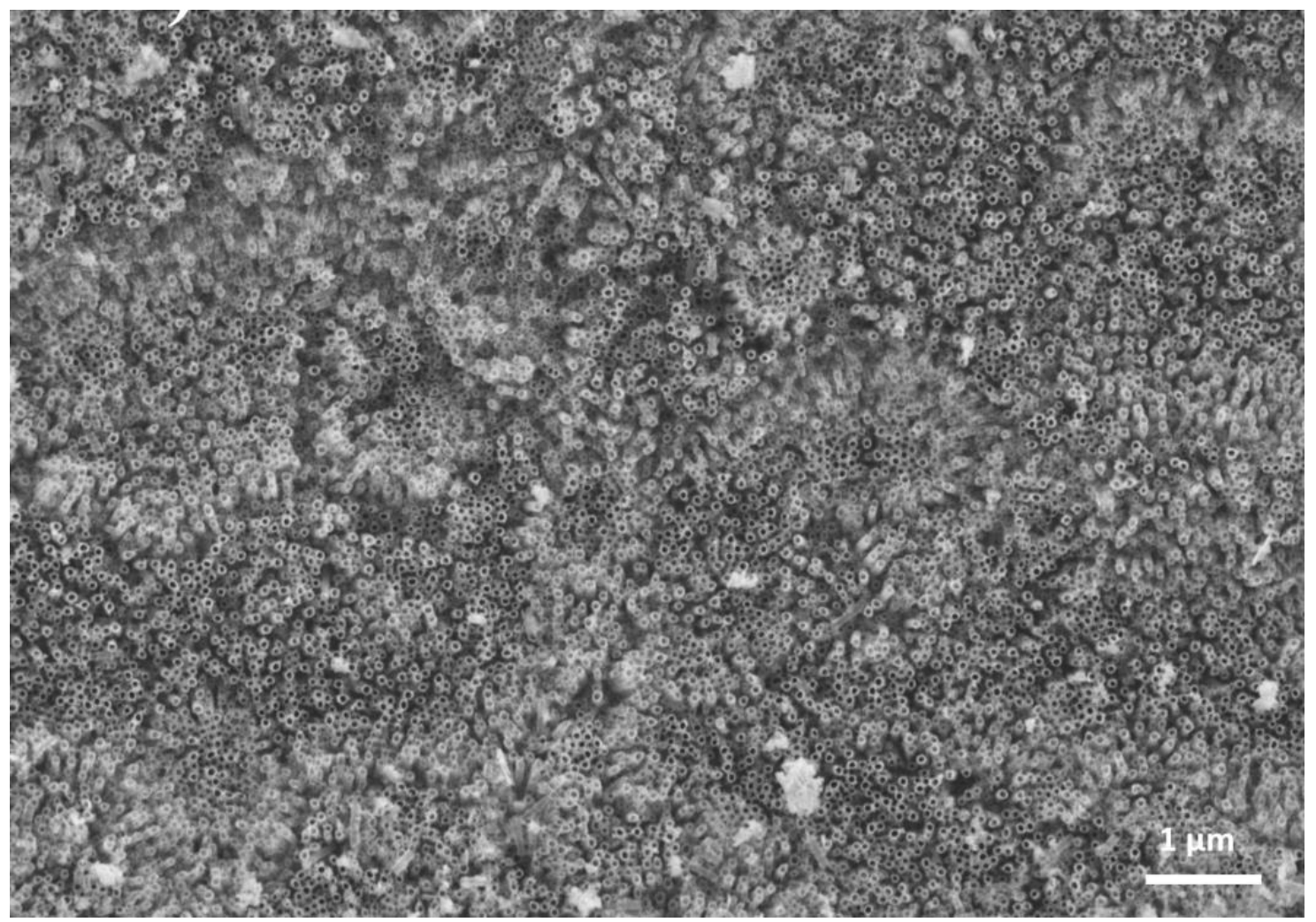

Figure 2. The Field Emission Scanning Electron Microscopy (FESEM) image surface topography of the Ti35Nb10Ta alloy after the anodic oxidation process.

Table 3. Surface chemical composition obtained with Energy Dispersive Spectroscopy (EDX).

\begin{tabular}{cccccc}
\hline \multirow{2}{*}{ Surface Treatment } & \multicolumn{6}{c}{ Chemical Composition (Weight \%) } \\
\cline { 2 - 6 } & $\mathbf{T i}$ & $\mathbf{N b}$ & $\mathbf{T a}$ & $\mathbf{O}$ & $\mathbf{F}$ \\
\hline Polished & 51 & 30 & 11 & 7 & 0 \\
Nanotubes 15 V 45 min & 29 & 26 & 6 & 33 & 5 \\
Nanotubes 15 V 45 min HT & 32 & 23 & 7 & 37 & 0.8 \\
\hline Note: HT: Heat treatment carried out in a vacuum sintering furnace at $320^{\circ} \mathrm{C}$ for 30 \\
\end{tabular}

After performing the anodic oxidation treatment, the EDS analysis detected a thicker stable oxide formation on all the titanium alloys surfaces. The amount of detected oxygen was around $30 \% \mathrm{wt}$. for the anodic oxidized samples. The anodic oxidation process did not only increase the amount of oxygen on the surface of the studied alloys, but also added a fluorine element to its chemical composition. Macak et al. (2007) [23] and Puckett et al. (2010) [24] have reported the presence of fluorine on the 
titanium nanotubes, which thus corroborates the results obtained herein. Electrolyte fluorine ions react with titanium to form a water-soluble $\left(\mathrm{TiF}_{6}\right)^{2-}$ complex [23]. This element may affect the osteoblast proliferation and differentiation [25], and could enhance the hydrophobic nature of the surface due to the low surface energy of the Ti-F bond. The heat treatment carried out at $320{ }^{\circ} \mathrm{C}$ for $30 \mathrm{~min}$ in a vacuum reduced the nanotube fluorine weight content from 5\% to $1 \%$ (Table 3 ). The main nanotube structure was preserved after heat treatment, and no visible changes in the diameter and shape of the $\mathrm{TiO}_{2}$ nanotubes were observed in FESEM.

The osseointegration process depends on the interaction between the cell and the implant surface. The topography, chemical composition and surface energy plays a significant role in the adhesion, differentiation and proliferation of cells [21]. Surface wettability depends on the interaction between the liquid and the titanium surface. Table 4 shows the contact angles for the four liquids used on all the tested surfaces. This table also reports the acid etching surface treatment done with the Ti6Al4V casting alloy for comparison purposes. This acid etched surface treatment is currently employed in commercial implants to improve cell adhesion [26-28]. The acid-etching samples were obtained in two separate stages; first, the samples were immersed in HF and then they were immersed in a mixture of $\mathrm{HCl}$ and $\mathrm{HF}$. In order to study the influence of the fluorine content on the surface energy of the beta titanium alloy, heat treatment was carried out after nanotube formation by the anodic oxidation process.

Table 4. Nanotube geometric characterization.

\begin{tabular}{ccccc}
\hline Surface Treatment & Water $\left(^{\circ}\right)$ & Glycerol $\left({ }^{\circ}\right)$ & Diiodomethane $\left(^{\circ}\right)$ & Formamide $\left(^{\circ}\right)$ \\
\hline Polished & $47 \pm 1$ & $77 \pm 8$ & $39 \pm 6$ & $30 \pm 5$ \\
Acid etched Ti6Al4V & $111 \pm 5$ & $94 \pm 1$ & $42 \pm 2$ & $89 \pm 1$ \\
Nanotubes 15 V 45 min & $140 \pm 5$ & $105 \pm 6$ & $34 \pm 2$ & $71 \pm 5$ \\
Nanotubes 35 V 45 min & $140 \pm 5$ & $125 \pm 7$ & $38 \pm 2$ & $61 \pm 3$ \\
Nanotubes 15 V 45 min HT & $109 \pm 2$ & $76 \pm 6$ & $31 \pm 6$ & $36 \pm 8$ \\
Nanotubes 35 V 45 min HT & $132 \pm 1$ & $87 \pm 7$ & $31 \pm 4$ & $35 \pm 2$ \\
\hline
\end{tabular}

Note: HT: Heat treatment carried out in a vacuum sintering furnace at $320^{\circ} \mathrm{C}$ for $30 \mathrm{~min}$.

Roughness and topographical features are some of the most relevant surface properties that modify the wettability behavior of the surfaces. A conventional acid-etched surface treatment is capable of modifying titanium surfaces within a microroughness range from 1 to $10 \mu \mathrm{m}$ [1]. The increased microroughness in the Ti6Al4V acid etched sample has increased the contact angle in the studied four liquids compared to the polished Ti35Nb10Ta surface (Table 4).

Nanotubular surfaces had much higher contact angles for each liquid used to determine the surface energy compared with the polished sample (Table 4), which indicates the nanotubular morphology that the highest surface energy had. The nanotube that formed after running the anodic oxidation process for $45 \mathrm{~min}$ and without heat treatment exhibited the biggest contact angle in water $\left(140^{\circ}\right)$ compared to the $47^{\circ}$ value obtained for the polished surface or the one of $109^{\circ}$ for the nanotubes obtained at $15 \mathrm{~V}$ and with heat treatment (Figure 3).

Nanotubular morphology and the fluorine content are considered two factors that increase the surface's hydrophobic nature [29-33]. Contact angles substantially increase for the nanotube surface; the layers with large contact angles display hydrophobic properties. After heat treatment the fluorine weight content lowered (Table 3), the contact angle in the studied four liquids reduced and surface wettability increased. The fluorine atoms displayed low polarizability and high electronegativity (3.98) compared to hydrogen (2.20) and titanium (1.54) [33]. The titanium-fluorine bonds are polarized due to the high electronegativity of fluorine. The lack of a permanent dipole moment contributes to increase the liquid surface hydrophobicity on the nanotube surfaces. The wettability of a solid surface by a liquid is determined by the liquid's surface tension, the solid surface's roughness and the solid's surface energy. The higher contact angle values found for the dark-stored nanotubes can 
be explained mainly by the hydrophobicity due to the Cassie-Bexter state where the liquid does not penetrate into the hollows of the nanotube surface and, consequently, faces a composite interface consisting of both solid and vapor; and also to the non-photoinduced hydrophilicity of $\mathrm{TiO}_{2}$ [32-37]. The nanotube morphology allowed the air still trapped inside the nanotubes and the behavior to become substantially hydrophobic [32,33].
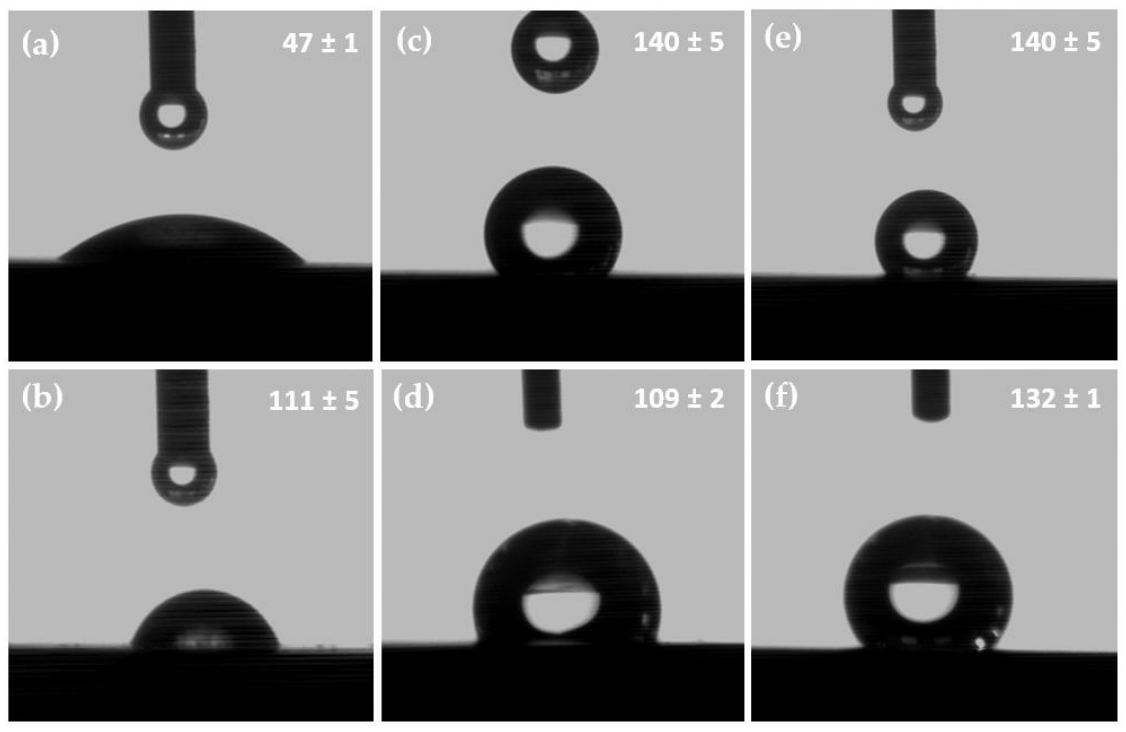

Figure 3. Water contact angles for the different titanium surface treatments. (a) Polished Ti6Al4V; (b) Acid etched Ti6Al4V; (c) Nanotubes in Ti35Nb10Ta obtained at $15 \mathrm{~V} 45 \mathrm{~min}$; (d) Nanotubes in Ti35Nb10Ta obtained at $15 \mathrm{~V} 45 \mathrm{~min}$ with heat treatment; (e) Nanotubes in Ti35Nb10Ta obtained at $35 \mathrm{~V} 45 \mathrm{~min}$; (f) Nanotubes in Ti35Nb10Ta obtained at $35 \mathrm{~V} 45$ min with heat treatment.

As previously described, the use of four liquids allows us to obtain the surface free energy values by the Owens-Wend method. Table 5 shows the values for the dispersive and polar component parts of the SFE. The dispersive component of the Ti35Nb10Ta alloy increased after the anodic oxidation process was applied, which initially took values of $26 \mathrm{~mJ} / \mathrm{m}^{2}$ for the polished samples, and increased to exceed $60 \mathrm{~mJ} / \mathrm{m}^{2}$ for the nanotubular surfaces. However, the polar component values lowered for the nanotubular surfaces compared with the polished samples. All the nanotubular surfaces displayed significantly higher surface free energy than the unmodified and polished Ti35Nb10Ta surfaces, and the microrough surfaces obtained in conventional acid etched Ti6Al4V alloys.

Table 5. Surface free energy for the different surfaces.

\begin{tabular}{cccc}
\hline Surface Treatment & $\begin{array}{c}\text { Total Surface Free } \\
\text { Energy } \mathbf{~} \mathbf{J} / \mathbf{m}^{\mathbf{2}}\end{array}$ & $\begin{array}{c}\text { Dispersive Component } \\
\mathbf{~} \mathbf{J} / \mathbf{m}^{\mathbf{2}}\end{array}$ & $\begin{array}{c}\text { Polar Component } \\
\mathbf{~} \mathbf{J} / \mathbf{m}^{\mathbf{2}}\end{array}$ \\
\hline $\begin{array}{c}\text { Polished } \\
\text { Acid etched Ti6Al4V }\end{array}$ & 50.2 & 26.2 & 23.9 \\
Nanotubes 15V 45min & 41.9 & 40.8 & 1.1 \\
Nanotubes 35V 45min & 80.1 & 66.3 & 13.9 \\
Nanotubes 15V 45min HT & 76.9 & 62.7 & 14.1 \\
Nanotubes 35V 45min HT & 65.9 & 64.6 & 1.3 \\
\hline
\end{tabular}

The nanotube formed in the Ti35Nb10Ta alloy had a smaller contact angle after being irradiated with UV light. The water contact angle for the polished Ti35Nb10Ta surfaces obtained an average value of $47^{\circ}$. After the samples had been stored in the dark for 2 weeks, the water contact angle increased to values that exceeded $100^{\circ}$, but the water contact angle reduced to $59^{\circ}$ after $30 \mathrm{~min}$ of 
UV irradiation. A smaller water contact angle for the UV-irradiated samples corresponded to a much higher wettability or hydrophilic property (Figure 4). Wang et al. [34] reported the same behavior for compact $\mathrm{TiO}_{2}$ surfaces. The anodic oxidized compact surfaces presented a water contact angle of $15^{\circ}$, the water contact angle increased to $72^{\circ}$ after been stored in the dark, and the contact angle reduced to $0^{\circ}$ after UV irradiation [34]. UV irradiation creates oxygen vacancies due to the formation of two coordinated bridging sites, which converts the corresponding $\mathrm{Ti}^{4+}$ sites to $\mathrm{Ti}^{3+}$ sites that enhance the amount of absorbed dissociated water and increase the surface free energy [35]. A gradual reversion of this hydrophilicity has been observed during dark storage [36].

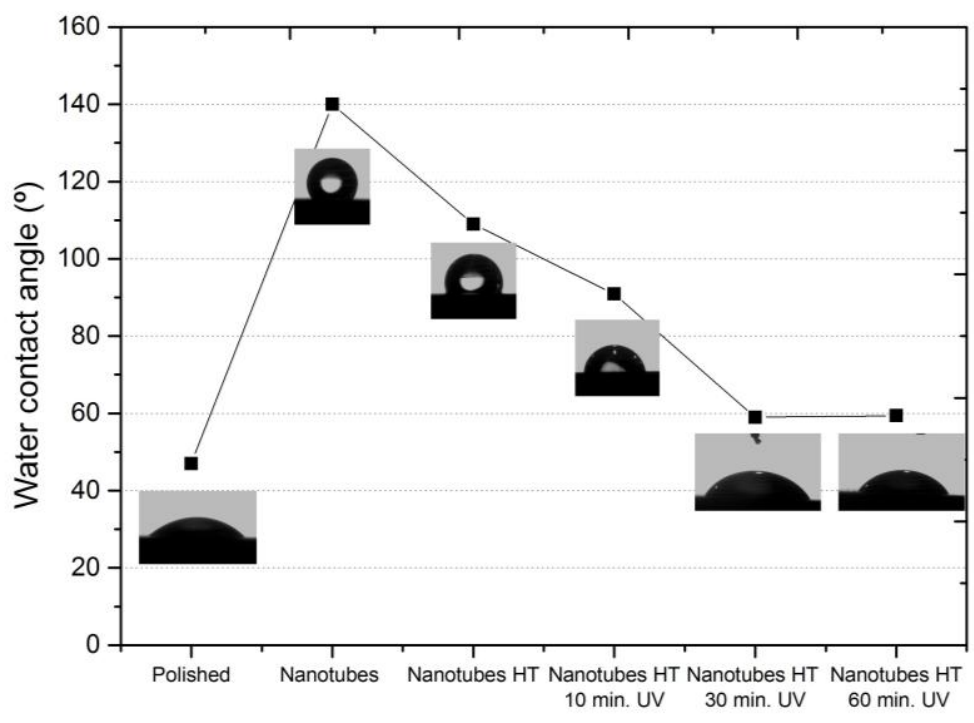

Figure 4. The water contact angle of the Ti35Nb10Ta $15 \mathrm{~V} 45 \mathrm{~min}$. nanotubes modified by UV irradiation.

The values of the roughness parameters for the polished and nanotubes Ti35Nb10Ta alloy studied herein are shown in Table 6. The anodic oxidation process modified the topography of the Ti35 $\mathrm{Nb} 10 \mathrm{Ta}$ surface by increasing the mean roughness and the quadratic average roughness values. These changes can be explained by the nanoscale modification of the titanium surface by the mechanism of chemical dissolution of $\mathrm{Ti}, \mathrm{Nb}$ and $\mathrm{Ta}$ metals due to the etching effect of the fluorine ions, and by oxidation due to the difference in the applied voltage. This phenomenon was also observed in the 2D and 3D profiles (Figure 5), obtained by employing the FRT Mark III ${ }^{\circledR}$ software, when the nanotube surface presented a nanoroughness that increased the surface area. Similar values of peak to valley roughness $\left(R_{z}\right)$ values were obtained on the polished and nanotube surfaces. These values can be explained by the residual porosity of the powder metallurgy samples, and are clearly observed in Figure 5b,c. Several studies have demonstrated that nanotubes topography is beneficial for the biomechanical anchorage of implants $[8,9,11,12,21]$.

Table 6. The roughness parameters for the Ti35Nb10Ta alloy.

\begin{tabular}{cccccccc}
\hline Roughness Parameters & $\boldsymbol{R}_{\boldsymbol{a}}(\boldsymbol{\mu \mathrm { m }})$ & $\boldsymbol{R}_{\boldsymbol{q}}(\boldsymbol{\mu \mathrm { m }})$ & $\boldsymbol{R}_{\boldsymbol{z}}(\mu \mathrm{m})$ & $\boldsymbol{R}_{\max }(\mu \mathrm{m})$ & $\boldsymbol{R}_{\boldsymbol{p}}(\mu \mathrm{m})$ & $\boldsymbol{R}_{p k}(\mu \mathrm{m})$ & $\boldsymbol{R}_{v k}(\mu \mathrm{m})$ \\
\hline Polished & 0.017 & 0.079 & 2.540 & 5.993 & 3.907 & 0.065 & 0.659 \\
Nanotubes & 0.200 & 0.252 & 2.174 & 2.339 & 1.317 & 0.250 & 0.248 \\
\hline
\end{tabular}


(a)

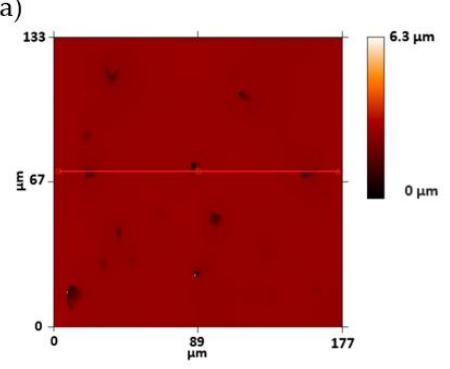

(d)

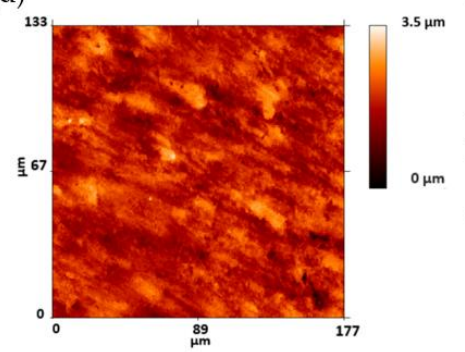

(b)

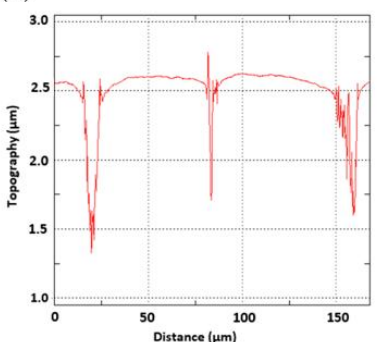

(e)

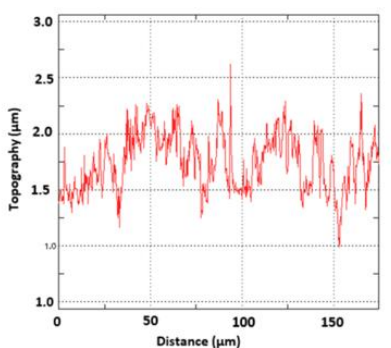

(c)

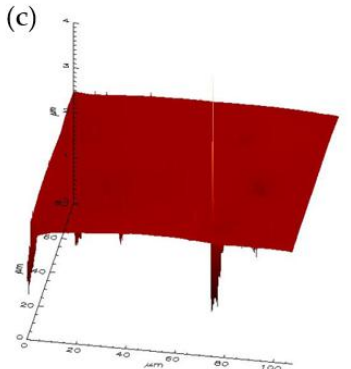

(f)

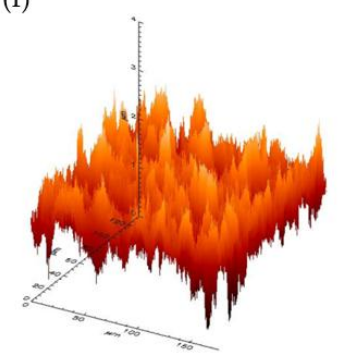

Figure 5. The surface roughness of the Ti35Nb10Ta alloy by confocal microscopy. (a) The 2D topographic roughness of the polished sample. (b) Roughness line profile of the polished sample. (c) The 3D topographic roughness of the polished sample. (d) The 2D topographic roughness of the $15 \mathrm{~V} 45 \mathrm{~min}$ nanotube sample. (e) Roughness line profile of the $15 \mathrm{~V} 45 \mathrm{~min}$ nanotube sample. (f) The $3 \mathrm{D}$ topographic roughness of the $15 \mathrm{~V} 45 \mathrm{~min}$ nanotube sample.

\section{Discussion}

The obtained Ti35Nb10Ta samples presented porosity that lowered the long-term mechanical performance, such as fatigue properties, which can make them unsuitable to be used as biomaterials if the recommendations of ASTM F136-02a are followed [18]. Mechanical Alloying (MA), Hot Isostatic Pressing (HIP) and Equal Channel Angular Pressing (ECAP) are alternative processing routes that can be employed to reduce or eliminate the residual porosity of powder metallurgical parts, and to increase chemical and phase homogeneity of the $\beta$ titanium alloys [38].

Modifying the wettability of $\mathrm{TiO}_{2}$ nanotubes is very interesting to increase cell adhesion, proliferation, differentiation, secretion of proteins and bone mineralization $[10,11,21,25]$. To date, the effect on the wettability and surface free energy of prolonged dark storage periods has not been reported for the $\mathrm{TiO}_{2}$ nanotubes. Our research showed how $\mathrm{TiO}_{2}$ nanotubes displayed a hydrophobic character after been stored in the dark for two weeks. This behavior can be attributed to both the Cassie-Bexter effect and the presence of retained fluorine ions inside the nanotubes. The contact angle measurements also indicated that the nanotube surface after heat treatment displayed a more hydrophilic character as compared to nanotubes surfaces. The water contact angle of the $\mathrm{TiO}_{2}$ nanotubes can be modified by the UV induced photocatalytic effect. Nanotube photoinduced hydrophilicity can be applied to biomaterials to increase the surface wettability of the implants after being stored for long periods and immediately before the implantation, which may increase bone anchorage and regeneration. Our research showed that the topography of beta titanium alloys can be modified on the nanoscale range through electrochemical process; this topography increased the surface area and consequently the probability for cell interlocking. Surface hydrophilicity is desired for cell attachment and osseointegration because it may increase the efficiency of nutrient delivery, gas exchange and waste excretion.

Apart from differences in topography, wettability and surface energy, the anodic oxidation process in an electrolyte that presents fluorine ions increased the oxide layer of the Ti35N10Ta alloy. Previous works have supported the hypothesis that these types of surface with nanotubes allow better cell 
adhesion compared to implants with roughened surfaces that have been obtained by grit-blasting followed by acid-etching [21,22]. Das et al. have demonstrated that anodic oxidation treatment with an anodized nanotube surface increases the osteoblast proliferation and enhances osteoblast-material interactions [21]. Salou et al. have reported how the removal torque of nanotubes surfaces is greater than grit-blasting and acid-etched implants, which implies that the osseointegration mechanism on nanotubes' surfaces is faster [22].

Several reports have shown that a stable nanotube titanium oxide layer, obtained after a heat treatment, improves long-term implant performance due to greater corrosion resistance and oxide layer stability, which translates into a lesser metal ion release from a titanium implant into the human body [17,39-42]. Mohan et al. reported an anatase phase for nanotubes after being annealed at $450{ }^{\circ} \mathrm{C}$. Nanotubes morphology obtained on this research present higher oxide thickness than the single passive layer formed on titanium alloys when exposed to air, improving the material corrosion resistance. Potentiodynamic polarization and electrochemical impedance studies have shown that the nanotubes surfaces exhibited better passivation behavior compared with a Ti6Al7Nb substrate [40]. Monetta et al. demonstrated that nanotubes present higher OCP values and a lower passive current in Hank's solution than an untreated Ti CP 2 material, which suggests better corrosion behavior of the nanotube surfaces [42].

The results of the present research indicate that anodic oxidation, heat treatment and UV irradiation processes are feasible treatments to obtain and modify the wettability and surface free energy of nanotubes on $\beta$ titanium alloys. Further research into hydroxyapatite grit blasting and double acid-etching processes is required to increase the roughness profile and to study the effect of nanotube formation on microroughness surfaces. The aim of these surface treatments is to enhance the mechanical interlocking between $\beta$ titanium implant surfaces and bone.

\section{Conclusions}

The studied Ti35Nb10Ta alloy was synthesized by a conventional powder metallurgy process, and presented a microstructural heterogeneity, composed predominantly of a $\beta$ phase with small $\alpha+\beta$ areas due to lack of diffusion of the refractory elements during sintering.

The anodic oxidation process, run with electrolyte composed of $\mathrm{H}_{3} \mathrm{PO}_{4}$ and $\mathrm{NaF}$, changed the topography and the chemical composition of the surface. This surface treatment created a nanotube oxide layer that added fluorine to its composition, and also increased the contact angle and surface free energy. This phenomenon is explained mainly by the Cassie-Bexter state and the by polarized titanium-fluorine bonds.

Heat treatment is a feasible post-treatment to remove the fluorine ions present in the nanotubes by preserving their structure, as appears in the FESEM images and EDX results taken on this research. The lower F/Ti ratio of nanotubes reduces the surface water contact angle. UV irradiation is a feasible treatment to increase the hydrophilicity of the nanotubes that have been stored in the dark for prolonged periods; this effect is explained by the photocatalytic effect of $\mathrm{TiO}_{2}$.

The surface roughness of the Ti35Nb10Ta was enhanced after the anodic oxidation process, which increased the surface area. Further in vitro and in vivo studies are required to study the effect of post-treatments (heat treatment and UV irradiation) on the nanotube osseointegration properties.

Acknowledgments: The authors wish to thank the Spanish Ministry of Economy and Competitiveness for the financially supportting Research Project MAT2014-53764-C3-1-R, the Generalitat Valenciana for support through PROMETEO 2016/040, the European Commission for FEDER funds that have allowed equipment to be purchased for research purposes, and also the Microscopy Service at the Polytechnic University of Valencia (UPV).

Author Contributions: Joan Lario wrote the paper and elaborated the data; Vicent Fombuena developed the contact angle and UV irradiation methodology; Ángel Vicente together with Joan Lario developed the powder metallurgy and anodic oxidation process; and Vicente Amigó conceived the project and made a substantial contribution to the interpretation of the data.

Conflicts of Interest: The authors declare no conflict of interest. 


\section{References}

1. Lario-Femenía, J.; Amigó-Mata, A.; Vicente-Escuder, Á.; Segovia-López, F.; Amigó-Borrás, V. Desarrollo de las aleaciones de titanio y tratamientos superficiales para incrementar la vida útil de los implantes. Rev. Met. 2016, 52, 1-13. [CrossRef]

2. Niinomi, M. Mechanical properties of biomedical titanium alloys. Mater. Sci. Eng. A 1998, 243, $231-236$. [CrossRef]

3. Lario, J.; Amigó, A.; Amigó, V. Effect of Ta, Nb Content and Sintering Temperature on the Microstructure, Mechanical Properties and Sinterability of Ti-Nb-Ta Alloys. In Proceedings of the World PM2016 Congress \& Exhibition, Hamburg, Germany, 9-13 October 2016; European Powder Metallurgy Association: Shrewsbury, UK, 2016.

4. Long, M.; Rack, H.J. Titanium alloys in total joint replacement-A materials science perspective. Biomaterials 1998, 19, 1621-1639. [CrossRef]

5. Niinomi, M. Mechanical biocompatibilities of titanium alloys for biomedical applications. J. Mech. Behav. Biomed. Mater. 2008, 1, 30-42. [CrossRef] [PubMed]

6. Cochran, D.L.; Schenk, R.K.; Lussi, A.; Higginbottom, F.L.; Buser, D. Bone response to unloaded and loaded titanium implants with a sandblasted and acid-etched surface: A histometric study in the canine mandible. J. Biomed. Mater. Res. 1998, 40,1-11. [CrossRef]

7. Gil, F.J.; Manzanares, N.; Badet, A.; Aparicio, C.; Ginebra, M.P. Biomimetic treatment on dental implants for short-term bone regeneration. Clin. Oral Investig. 1998, 18, 59-66. [CrossRef] [PubMed]

8. Tan, W.; Pingguan-Murphy, B.; Ahmad, R.; Akbar, S.A. Review of titania nanotubes: Fabrication and cellular response. Ceram. Int. 2012, 38, 4421-4435. [CrossRef]

9. Minagar, S.; Berndt, C.C.; Wang, J.; Ivanova, E.; Wen, C. A review of the application of anodization for the fabrication of nanotubes on metal implant surfaces. Acta Biomater. 2012, 8, 2875-2888. [CrossRef] [PubMed]

10. Elias, C.N.; Oshida, Y.; Lima, J.H.C.; Muller, C.A. Relationship between surface properties (roughness, wettability and morphology) of titanium and dental implant removal torque. J. Mech. Behav. Biomed. Mater. 2008, 1, 234-242. [CrossRef] [PubMed]

11. Brammer, K.S.; Oh, S.; Cobb, C.J.; Bjursten, L.M.; van der Heyde, H.; Jin, S. Improved bone-forming functionality on diameter-controlled $\mathrm{TiO}_{2}$ nanotube surface. Acta Biomater. 2009, 5, 3215-3223. [CrossRef] [PubMed]

12. Sista, S.; Nouri, A.; Li, Y.; Wen, C.; Hodgson, P.D.; Pande, G. Cell biological responses of osteoblasts on anodized nanotubular surface of a titanium-zirconium alloy. J. Biomed. Mater. Res. Part A 2013, 101, 3416-3430. [CrossRef] [PubMed]

13. Ponsonnet, L.; Reybier, K.; Jaffrezic, N.; Comte, V.; Lagneau, C.; Lissac, M.; Martelet, C. Relationship between surface properties (roughness, wettability) of titanium and titanium alloys and cell behavior. Mater. Sci. Eng. C 2003, 23, 551-560. [CrossRef]

14. Okazaki, Y.; Gotoh, E. Comparison of metal release from various metallic biomaterials in vitro. Biomaterials 2005, 26, 11-21. [CrossRef] [PubMed]

15. Huang, H.H.; Wu, C.P.; Sun, Y.S.; Lee, T.H. Improvements in the corrosion resistance and biocompatibility of biomedical Ti-6Al-7Nb alloy using an electrochemical anodization treatment. Thin Solid Films 2013, 528, 157-162. [CrossRef]

16. Eisenbarth, E.; Velten, D.; Müller, M.; Thull, R.; Breme, J. Biocompatibility of $\beta$-stabilizing elements of titanium alloys. Biomaterials 2004, 25, 5705-5713. [CrossRef] [PubMed]

17. Bauer, S.; Pittrof, A.; Tsuchiya, H.; Schmuki, P. Size-effects in $\mathrm{TiO}_{2}$ nanotubes: Diameter dependent anatase/rutile stabilization. Electrochem. Commun. 2011, 13, 538-541. [CrossRef]

18. Prasan, K.; Newkirk, J. Powder Metallurgy. In ASM Handbook; ASM International: Materials Park, OH, USA, 1998; Volume 7, p. 907. ISBN 978-1-62708-089-3.

19. Lario, J.; Viera, M.; Segovia, F.; Amigó, V. Influence of electrolyte composition on the growth of $\mathrm{TiO}_{2}$ Nanotubes on $\beta$ titanium alloys. In Proceedings of the Euro PM2017 Congress \& Exhibition, Milano, Italy, 1-5 October 2017; European Powder Metallurgy Association (EPMA): Shrewsbury, UK, 2016. 
20. Lario, J.; Vicente, A.; Amigó, A.; Segovia, F.; Amigó, V. Influencia del voltaje en la formación de nanotubos en aleaciones $\alpha, \alpha+\beta$ y $\beta$ de titanio. In Proceedings of the XXXIV Congreso Anual de la Sociedad Española de Ingeniería Biomédica, Valencia, Spain, 23-25 November 2016; pp. 164-167.

21. Das, K.; Bose, S.; Bandyopadhyay, $\mathrm{A}$. $\mathrm{TiO}_{2}$ nanotubes on Ti: Influence of nanoscale morphology on bone cell-materials interaction. J. Biomed. Mater. Res. Part A 2009, 90, 225-237. [CrossRef] [PubMed]

22. Salou, L.; Hoornaert, A.; Louarn, G.; Layrolle, P. Enhanced osseointegration of titanium implants with nanostructured surfaces: An experimental study in rabbits. Acta Biomater. 2015, 11, 494-502. [CrossRef] [PubMed]

23. Macak, J.M.; Tsuchiya, H.; Ghicov, A.; Yasuda, K.; Hahn, R.; Bauer, S.; Schmuki, P. TiO 2 nanotubes: Self-organized electrochemical formation, properties and applications. Curr. Opin. Solid State Mater. Sci. 2007, 11, 3-18. [CrossRef]

24. Puckett, S.D.; Taylor, E.; Raimondo, T.; Webster, T.J. The relationship between the nanostructure of titanium surfaces and bacterial attachment. Biomaterials 2010, 31, 706-713. [CrossRef] [PubMed]

25. Bayram, C.; Erdal, E.; Karahalilo, Z.; Baki, E. Titania nanotubes with adjustable dimensions for drug reservoir sites and enhanced cell adhesion. Mater. Sci. Eng. C Mater. Biol. Appl. 2014, 35, 100-105. [CrossRef]

26. Le Guéhennec, L.; Soueidan, A.; Layrolle, P.; Amouriq, Y. Surface treatments of titanium dental implants for rapid osseointegration. Dent. Mater. 2007, 23, 844-854. [CrossRef] [PubMed]

27. Chen, J.; Zhang, Z.; Ouyang, J.; Chen, X.; Xu, Z.; Sun, X. Bioactivity and osteogenic cell response of $\mathrm{TiO}_{2}$ nanotubes coupled with nanoscale calcium phosphate via ultrasonification-assisted electrochemical deposition. Appl. Surf. Sci. 2014, 305, 24-32. [CrossRef]

28. Wen, H.B.; Liu, Q.; de Wijn, J.R.; de Groot, K.; Cui, F.Z. Preparation of bioactive microporous titanium surface by a new two-step chemical treatment. J. Mater. Sci. Mater. Med. 1998, 9, 121-128. [CrossRef]

29. Bharathidasan, T.; Narayanan, T.N.; Sathyanaryanan, S.; Sreejakumari, S.S. Above $170^{\circ}$ water contact angle and oleophobicity of fluorinated graphene oxide based transparent polymeric films. Carbon 2015, 84, 207-213. [CrossRef]

30. Yao, W.; Li, Y.; Huang, X. Fluorinated poly(meth)acrylate: Synthesis and properties. Polymer 2014, 55, 6197-6211. [CrossRef]

31. Zha, J.; Ali, S.S.; Peyroux, J.; Batisse, N.; Claves, D.; Dubois, M.; Kharitonov, A.P.; Monier, G.; Darmanin, T.; Guittard, F.; et al. Superhydrophobicity of polymer films via fluorine atoms covalent attachment and surface nano-texturing. J. Fluor. Chem. 2017, 200, 123-132. [CrossRef]

32. Peters, A.M.; Pirat, C.; Sbragaglia, M.; Borkent, B.M.; Wessling, M.; Lohse, D. Cassie-Baxter to Wenzel state wetting transition: Scaling of the front velocity. Eur. Phys. J. E 2009, 397, 391-397. [CrossRef] [PubMed]

33. Giacomello, A.; Meloni, S.; Chinappi, M.; Casciola, C.M. Cassie-baxter and wenzel states on a nanostructured surface: Phase diagram, metastabilities, and transition mechanism by atomistic free energy calculations. Langmuir 2012, 28, 10764-10772. [CrossRef] [PubMed]

34. Wang, R.; Hashimoto, K.; Fujishima, A.; Chikuni, M.; Kojima, E.; Kitamura, A.; Shimohigoshi, M.; Watanabe, T. Photogeneration of Highly Amphiphilic $\mathrm{TiO}_{2}$ Surfaces. Adv. Mater. 1998, 10, 135-138. [CrossRef]

35. Liu, Z.; Wang, Y.; Peng, X.; Li, Y.; Liu, Z.; Liu, C.; Ya, J.; Huang, Y. Photoinduced superhydrophilicity of TiO 2 thin film with hierarchical Cu doping. Sci. Tech. Adv. Mater. 2012, 13, 1-5. [CrossRef] [PubMed]

36. Liu, Y.; Lin, Z.; Lin, W.; Moon, K.S.; Wong, C.P. Reversible Superhydrophobic-Superhydrophilic Transition of $\mathrm{ZnO}$ Nanorod/Epoxy Composite Films. ACS Appl. Mater. Interfaces 2012, 8, 3959-3964. [CrossRef] [PubMed]

37. Wang, R.; Hashimoto, K.; Fujishima, A.; Chikuni, M.; Kojima, E.; Kitamura, A.; Shimohigoshi, M.; Watanabe, T. Light-induced amphiphilic surfaces. Nature 1997, 388, 431-432. [CrossRef]

38. Viera, M.; Lario, J.; Vicente, A. Influence of $\mathrm{Nb}$ Content on Microstructure and Mechanical Properties of Powder Sintered Ti-Nb-Mo Alloys. In Proceedings of the Euro PM2016 Congress \& Exhibition, Hamburg, Germany, 9-13 October 2016; European Powder Metallurgy Association (EPMA): Shrewsbury, UK, 2016.

39. Zhao, Y.; Xiong, T.; Huang, W. Effect of heat treatment on bioactivity of anodic titania films. Appl. Surf. Sci. 2010, 256, 3073-3076. [CrossRef]

40. Mohan, L.; Anandan, C.; Rajendran, N. Electrochemical behavior and effect of heat treatment on morphology, crystalline structure of self-organized $\mathrm{TiO}_{2}$ nanotube arrays on Ti-6Al-7Nb for biomedical applications. Mater. Sci. Eng. C Mater. Biol. Appl. 2015, 50, 394-401. [CrossRef] [PubMed] 
41. Bai, Y.; Park, I.S.; Park, H.H.; Lee, M.H.; Bae, T.S.; Duncan, W.; Swain, M. The effect of annealing temperatures on surface properties, hydroxyapatite growth and cell behaviors of $\mathrm{TiO}_{2}$ nanotubes. Surf. Interface Anal. 2011, 43, 998-1005. [CrossRef]

42. Monetta, T.; Acquesta, A.; Carangelo, A.; Bellucci, F. TiO 2 Nanotubes on Ti Dental Implant. Part 1: Formation and Aging in Hank's Solution. Metals 2017, 7, 167. [CrossRef] 